\title{
Reclamation of ecological functions within a marine ecosystem: redevelopment of the Southeast False Creek lands in Vancouver, Canada
}

\author{
M. A. Adams ${ }^{1}$, B. G. Wernick ${ }^{2}$ \& L. H. Nikl ${ }^{2}$ \\ ${ }^{I}$ Envirowest Consultants Inc., Burnaby, Canada \\ ${ }^{2}$ Golder Associates Ltd., Vancouver, Canada
}

\begin{abstract}
The Southeast False Creek (SEFC) lands occur within Vancouver, British Columbia, Canada. The comprehensive redevelopment of the shoreline of the SEFC Lands included modification of the marine environment. Redevelopment impacted marine fish habitats as defined by the federal Fisheries Act. In accordance with the Act, the overall redevelopment was required to create habitats to compensate for impacts.

The statutory requirement to create habitats does not pursue the restoration of ecological functions within the affected environment. In contrast, the design of the SEFC shoreline embraces the process of ecological restoration. The design, however, acknowledges that redevelopment cannot restore the shoreline to its original natural condition. It can, though, reclaim ecological functions within False Creek. In this regard, ecological reclamation defines the design philosophy for redevelopment of the SEFC shoreline.

Redevelopment of the shoreline has resulted in significant enhancement of the False Creek ecosystem. The delivery of new fish habitats is a byproduct of the reclamation of ecological functions. Marine life, typical of southwestern British Columbia, has benefited from enhancement efforts. Residents of Vancouver, themselves part of the False Creek ecosystem, are also afforded benefits. Exposure to the dynamics of the ecosystem fosters an appreciation of the natural condition, which evolves into a sense of ownership and stewardship, and, ultimately, conservation of ecological functions.

Keywords: Southeast False Creek, ecological reclamation, ecological restoration, ecological design, ecosystem enhancement, marine enhancement, habitat island.
\end{abstract}




\section{Introduction}

The Southeast False Creek (SEFC) lands occur within Vancouver, British Columbia, Canada (49 $\left.16^{\prime} 20^{\prime \prime} \mathrm{N} / 123^{\circ} 06^{\prime} 33^{\prime \prime}\right)$. The lands are aligned along the southeast shoreline of False Creek which is, in turn, aligned along the southern margin of the downtown core of Vancouver.

The history of shoreline development of False Creek is summarized by Wernick et al. [1]. Upon the decline in industry during the 1970s, much of the backshore lands of False Creek laid vacant. The lands surrounding the eastern part of False Creek were used for the 1986 World Exposition. The predominant shoreline treatment associated with the exposition consisted of large-diameter riprap at a slope ratio of 2 horizontal to 1 vertical from top- to the toe-of-bank, and an asphalt- surfaced trail and ornamental landscaping landward of the top-ofbank.

The redevelopment of the SEFC Lands is predicated upon the SEFC Official Community Plan (ODP) approved by Vancouver City Council in 2005. The ODP encapsulates approximately 32 hectares which will ultimately be home to about 15,000 people. Redevelopment was initiated with the construction of the Olympic Village for the 2010 Winter Olympics. A key element of the ODP is the creation of a shoreline park fronting the lands. Most of the park was created concurrent with construction of the Olympic Village.

In this paper we present the foundation for the environmental design of the shoreline, in particular, reclamation of ecological functions associated with the False Creek ecosystem.

\section{Environmental and regulatory setting}

The shoreline park of the SEFC Lands is nested within a highly urbanized landscape (Figure 1). The historical natural shoreline occurs approximately 300 metres landward of the development shoreline. Past industrial development of the SEFC Lands was founded on fill placed within False Creek.

False Creek is a small inlet that is contiguous with English Bay at the opening of a far larger inlet, Burrard Inlet. Historically, False Creek was surrounded by vast expanses of coniferous forest [2]. Numerous streams drained into the inlet; many of these streams supported populations of several species of Pacific salmon [2]. Tidal flats were a conspicuous feature of False Creek. The mudflats and marshes of the inlet supported a rich assemblage of birds during all or part of their life-history [2]. Fishes included species characteristic of estuarine and marine environments of coastal British Columbia [2]. Marine mammals that visited the inlet included seals and whales [2]. The ecosystem of historical False Creek was rich and diverse.

Development of False Creek and surrounding environs eliminated many of the elements of this historical ecosystem. The historic fill that characterizes the SEFC Lands is also characteristic of all of False Creek. The eastern third of the inlet was completely filled. Tidal flats surrounding the inlet were filled. The 


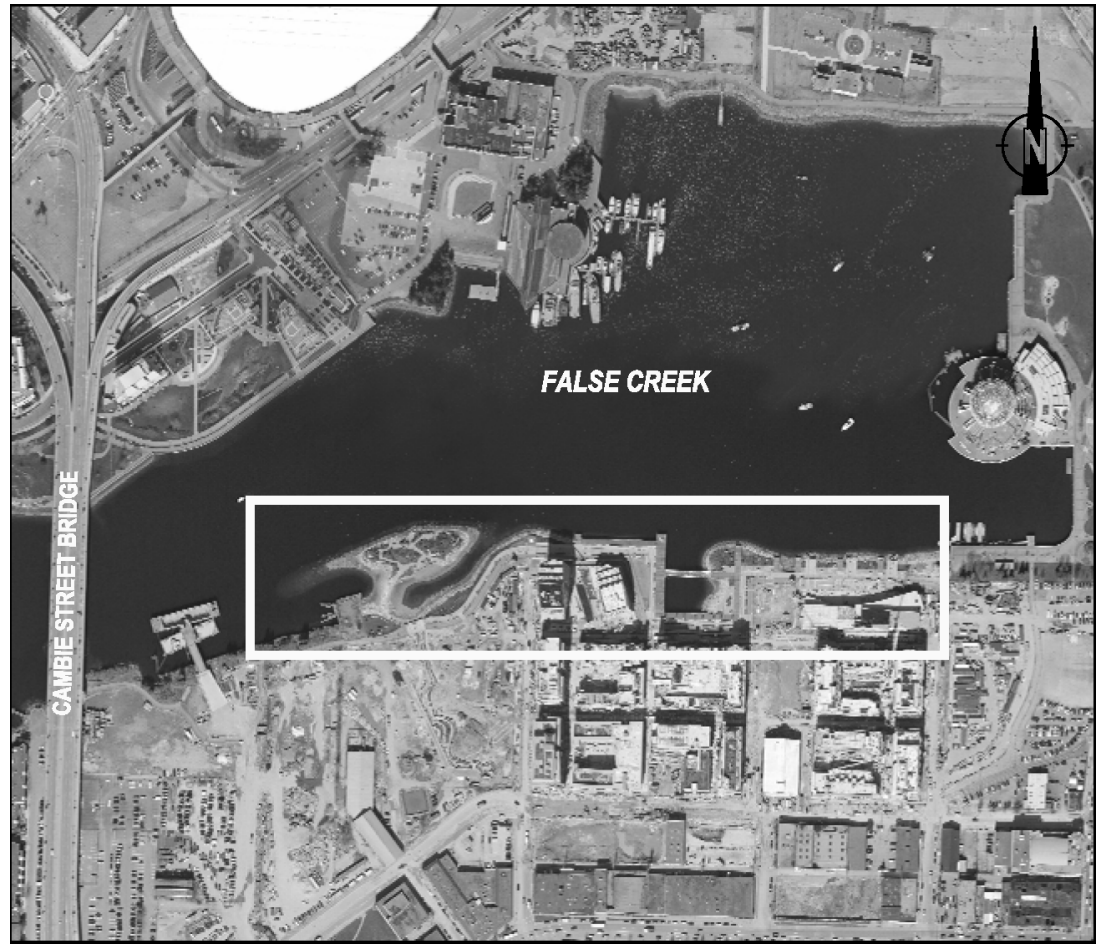

Figure 1: Location of Southeast False Creek during construction (photograph courtesy of the City of Vancouver).

streams of the False Creek watershed were enclosed within storm and combined sewers. The coniferous forests that surrounded the inlet were replaced by residential, commercial and industrial development.

Key aspects of the redevelopment of the shoreline of SEFC Lands are presented by Wernick et al. [1]. Redevelopment included partial filling of an embayment that once hosted industrial uses. Fill within the embayment impacted fish habitat as defined by the federal Fisheries Act [1]. In accordance with the Act, the overall redevelopment of the shoreline had to include replacement habitats that compensated for impacts to existing habitats.

\section{Environmental design}

\subsection{Design philosophy}

The statutory requirement to replace impacted habitats does not embrace a broad ecosystem approach. The focus is upon creating habitats for fish. It is often myopic in its approach: the requirement often results in the construction of features for fish independent of the ecological setting within which the replacement habitats are created. 
In this regard, habitat creation is not ecological restoration. Often, habitat creation is represented by environmental professionals as habitat restoration. Habitat restoration, as such, is not ecological restoration. Ecological restoration is far more comprehensive an act than that of habitat restoration.

Ecological restoration is "the process of assisting the recovery of an ecosystem that has been degraded, damaged, or destroyed" [3]. This definition, however, does not define the endpoint of ecological restoration. Bradshaw $[4,5]$ provides some clarity and structure in this regard. He references the Oxford English Dictionary [6] for an unadulterated definition for restoration. Restoration is the "act of restoring to a former state or position ... or to an unimpaired or perfect condition." Further, to restore is "to bring back to the original state... or to a healthy or vigorous state" [6]. Hence, restoration may be considered as an act of turning back the clock, to return to the original condition that is unimpaired by subsequent events.

The design of the SEFC shoreline embraces the process that the Society for Ecological Restoration [3] defines as ecological restoration. It did not constrain itself to simply creating fish habitats. However, there was never any potential to return the shoreline to its original condition. The design, rather, was focused upon creating elements along the shoreline that enhanced the capacity of the False Creek ecosystem to provide ecological functions for marine life typical of the southwest coast of British Columbia.

Bradshaw [4, 5] presents several terms that are sometimes used synonymously with restoration. The terms include rehabilitation, remediation, reclamation and replacement. Of these terms, reclamation best describes the process that was pursued for the SEFC shoreline. Reclamation is often defined as "the making of land fit for cultivation". It is typically associated with creating land out of aquatic environments (e.g. dyking) for agriculture. In itself, this can be hardly considered analogous to restoration. But, to reclaim is defined as "to bring back to a proper state" [6]. The endpoint is the return to a useful state [4, 5], in this instance, useful to the ecosystem of False Creek. So, as the result of the perpetual creation and evolution of terminology, the term 'ecological reclamation' is created and defined as 'the proper enhancement of an ecosystem that has been degraded or damaged'. Ecological reclamation defines the design philosophy for the SEFC shoreline.

\subsection{Components of design}

The challenge for the ecological reclamation of the SEFC shoreline was the identification and selection of features to be incorporated within the overall design of the shoreline. The ecological design had to acknowledge other aspects of the design of the shoreline park, in particular those aspects associated with recreational use of the park by the residents of Vancouver.

It was important that the main features of the ecological design appear to be the result of a natural progression from other parts of the shoreline park that are conventional elements of urban park design. In this regard, the design borrowed aspects of the character of other shoreline environments of southwestern British Columbia defined by a combination of natural and development features. 
Islands are common throughout coastal British Columbia. Often, shoreline developments fill the channels between the mainland and the islands. The natural character of the island is often lost to development; in some instances, however, the island retains much of its natural character. The natural character of the island is recognizable, but the effects of development are apparent.

In consideration of the filling of False Creek that was associated with historical development of the inlet, the ecological design mimicked the hybrid character of partially developed shorelines involving islands. Three islands, displaying varying degrees of independence from the mainland, are part of the overall design of the shoreline (Figure 2). The largest and most conspicuous of these islands is known locally as 'Habitat Island'. It is intended that over time, park users will perceive these islands as natural features of False Creek, as part of the natural heritage of the inlet.

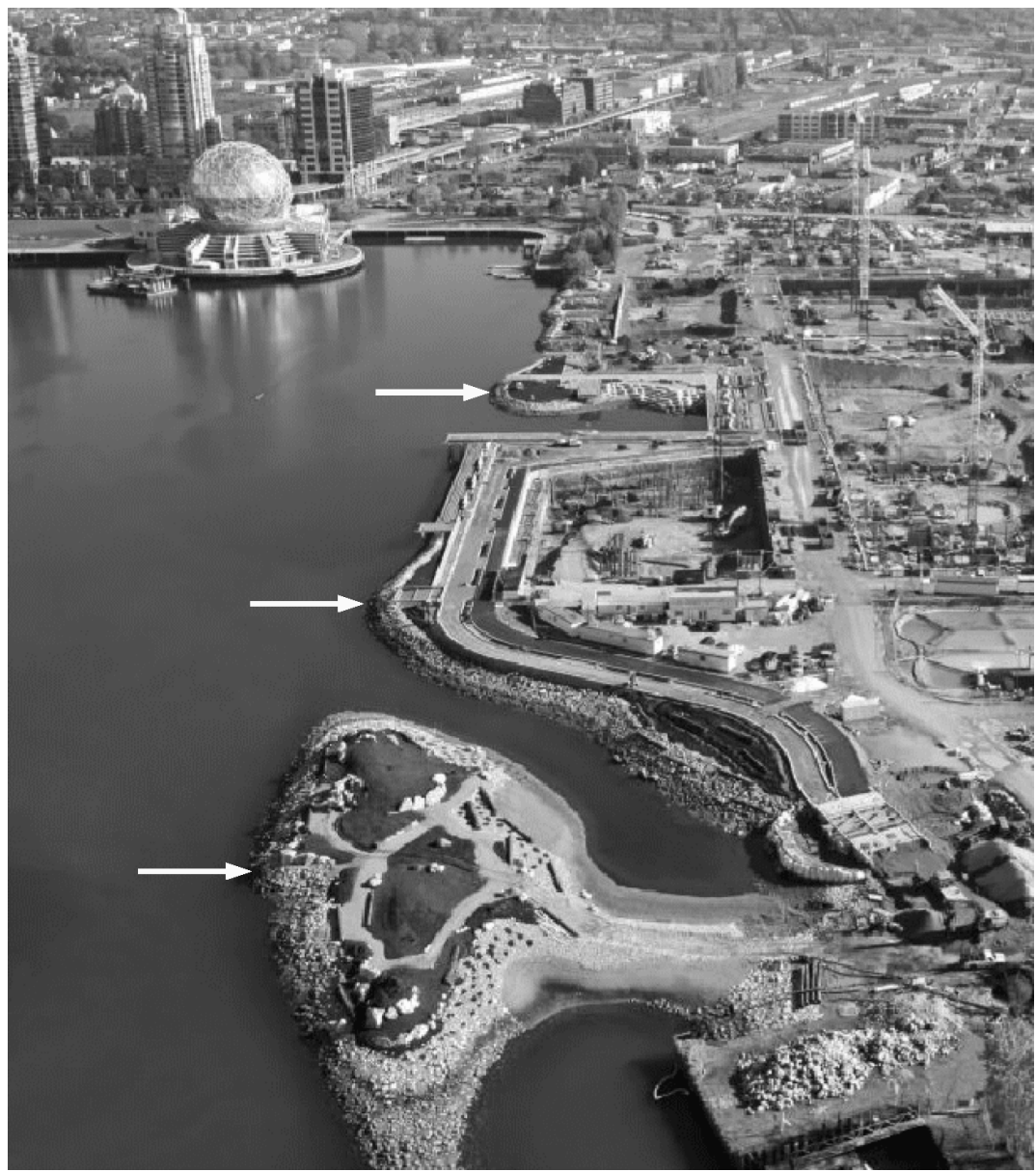

Figure 2: 'Islands' of Southeast False Creek shoreline during construction (photograph courtesy of the City of Vancouver). 
The portrayal of these islands as natural features of the inlet is contingent upon the specific ecological design of the islands. This design is, in turn, dependent on features that sustain ecological functions for marine life, functions that are part of the False Creek ecosystem. These ecosystem functions are dependent upon physical design elements.

Physical attributes of a feature define its structure. Structure is a strong determinant of the ecological functions that can be sustained by a feature $[7,8]$. In general, as complexity in structure increases, so does the number of functions that can be sustained.

The epibenthic and benthic communities of marine environments are a foundational element of the overall ecosystem. The diversity and productivity of these communities are dependent upon both substrate types and the bathymetric character of the intertidal and nearshore subtidal bottom $[9,10]$.

The substrate types, elevations and grades incorporated by the design of Habitat Island illustrate the complexity of the physical component of the ecological design of the SEFC shoreline. A mosaic of substrate types are laid out along the design bathymetry of the island (Figures 3, 4 and 5). Substrate types include sands, gravels, cobbles and boulders. All of these substrates are rounded, typical of natural shoreline environments. Near-flat grades are dressed with smaller substrates; steeper grades are dressed with larger substrates. The high complexity of substrate types and associated grades enhances the potential of Habitat Island to sustain a high number of ecological functions for marine life.

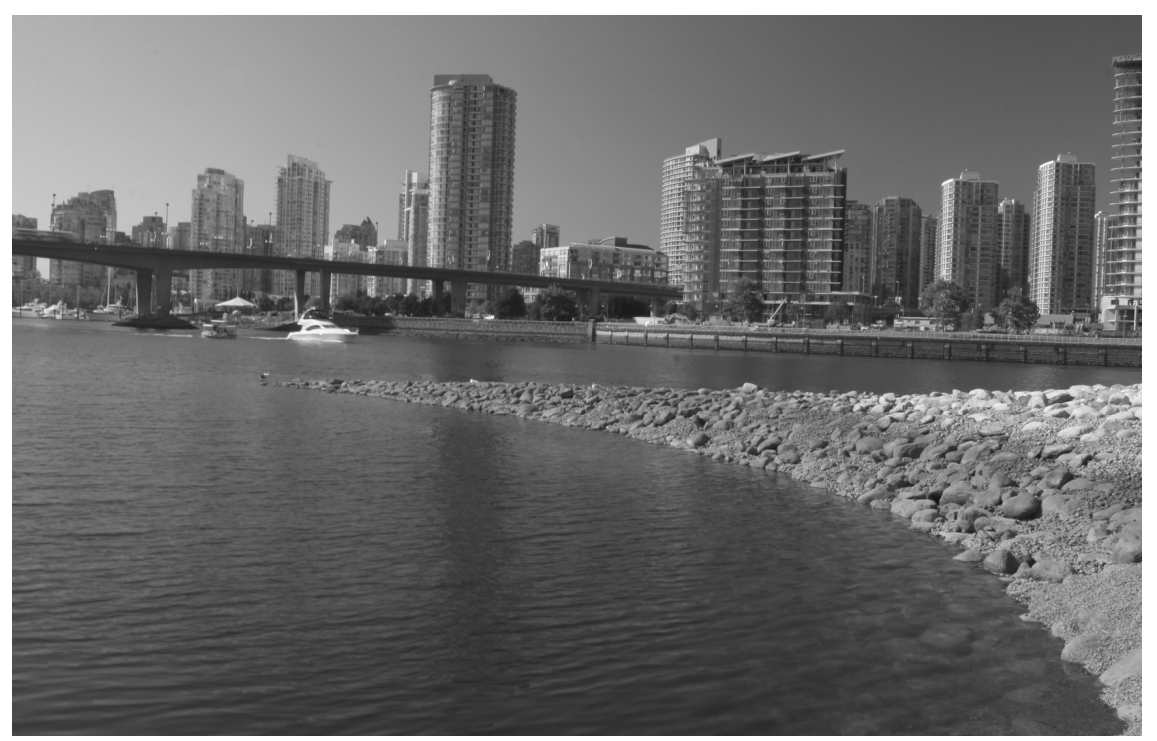

Figure 3: Large boulders of the western spit of Habitat Island (looking northwest). 


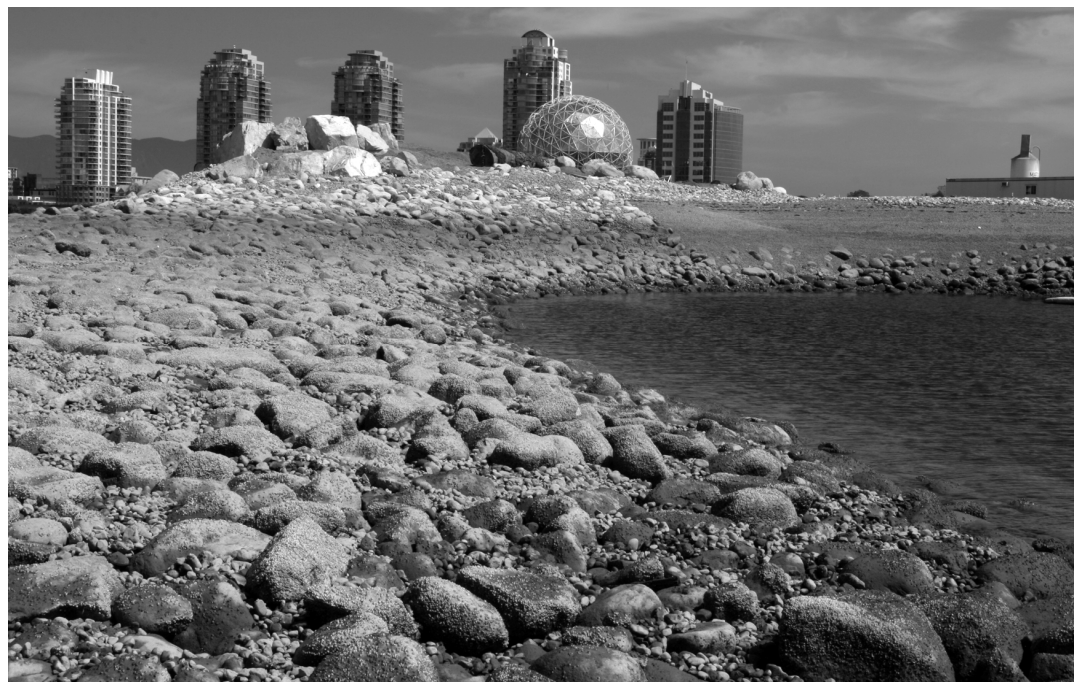

Figure 4: Looking east from the western spit of Habitat Island. Note the large boulders are infilled with gravel. A sand-gravel beach is contiguous with the head of the spit.

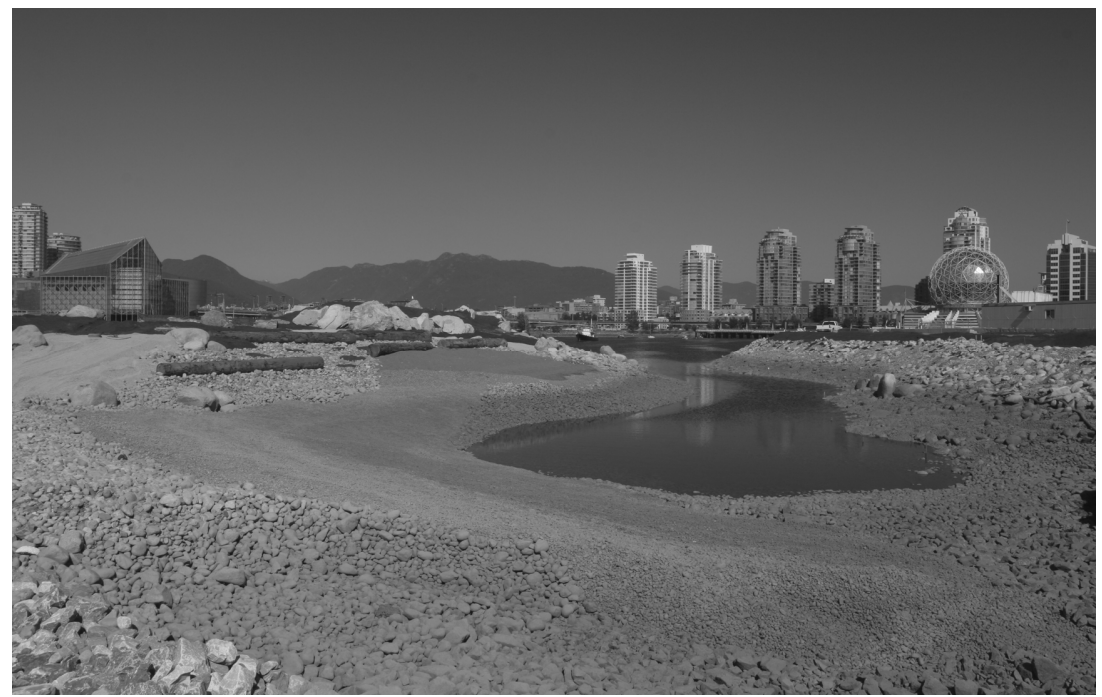

Figure 5: Small embayment at eastern end of Habitat Island. Substrates of the embayment include sands, gravels, cobbles and boulders.

The design prescribes plantings throughout the intertidal and immediate backshore zones (Figures 6, 7 and 8) of Habitat Island. Native salt marsh species are planted within middle to high elevations of the intertidal zone. Plants typical of marine dune assemblages are planted within sands and gravels at and about 
the high water mark. The backshore zone of the island, dressed with topsoils, is planted with species typical of the salt spray zone of coastal British Columbia. Ecological functions for marine life are further enhanced by the placement of snags and logs upon the surface of the island.

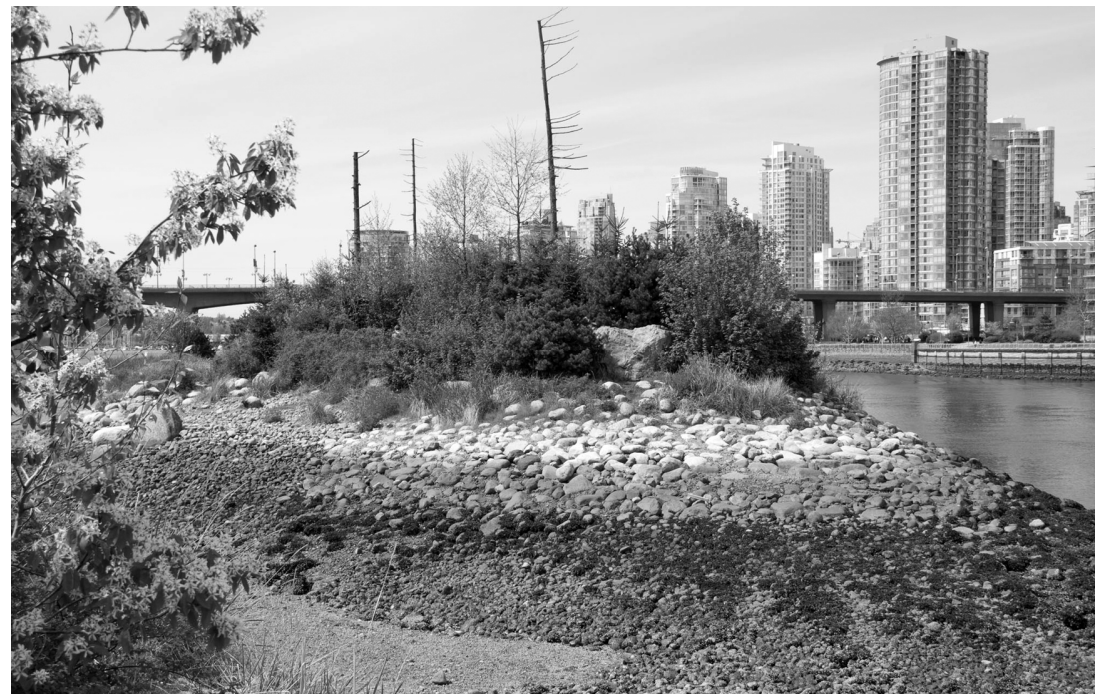

Figure 6: Eastern tip of Habitat Island looking west at the natural assemblage of native plant species throughout the intertidal and backshore zones of the island.

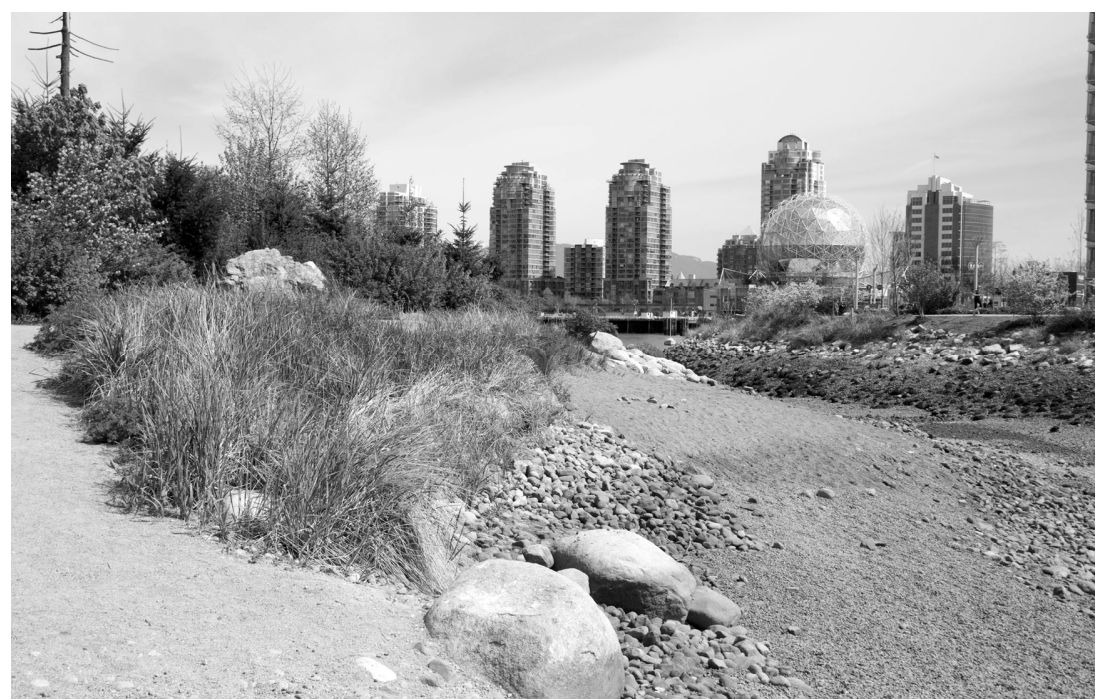

Figure 7: Dune and marsh plant species of the embayment along the southern shoreline of Habitat Island. 


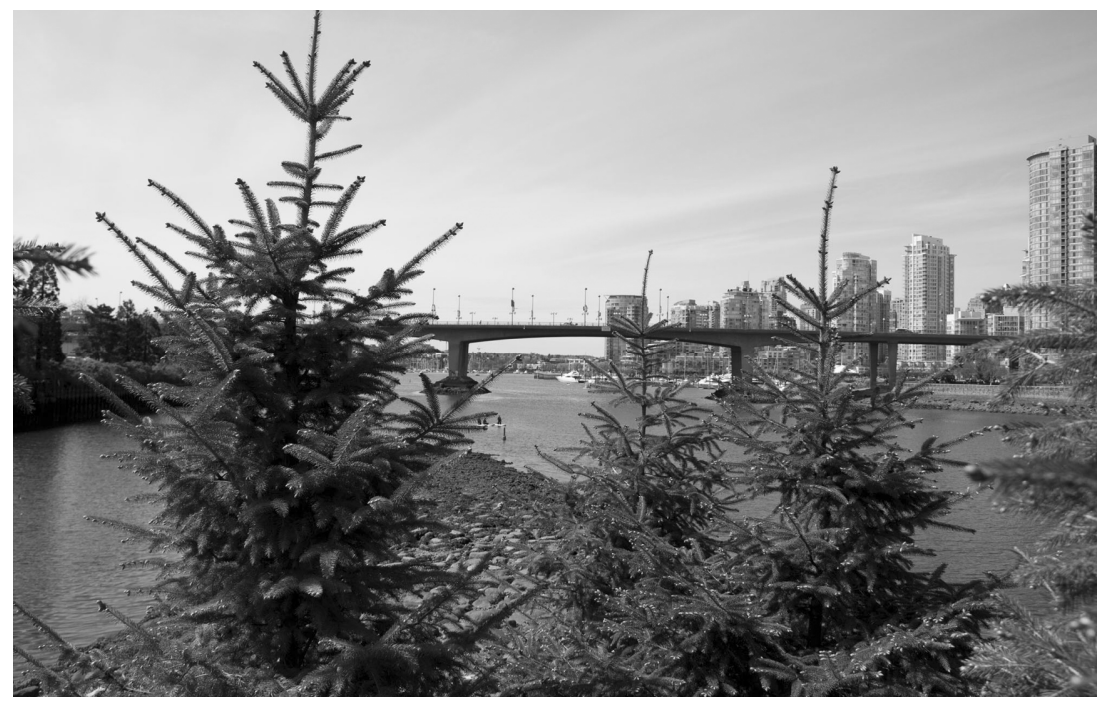

Figure 8: Looking west at the spit through coniferous trees from the backshore zone of Habitat Island.

Habitat Island is accessible from the mainland during lower high to low tides. To facilitate an appreciation of the natural character of this feature by park users, a gravel path circumnavigates the island. The False Creek ecosystem can be readily engaged by park users.

\section{Discussion and summary}

Redevelopment of the SEFC Lands included the creation of a shoreline park. Redevelopment impacted fish habitats as defined by the federal Fisheries Act. As required by the Act, fish habitats had to be created to compensate for impacts to fish habitats.

The design of the shoreline park did not limit itself to simply creating fish habitat as an ancillary feature of the park. The design was far more ambitious in terms of its objectives. The design, or more so, the ecological design of the park seeks to enhance the damaged and degraded ecosystem of False Creek. Ecological reclamation defines the design philosophy for the shoreline component of redevelopment of the SEFC Lands.

Through ecological reclamation of the shoreline fronting the SEFC Lands, redevelopment created the fish habitats required to satisfy the compensation requirements of the Fisheries Act. These habitats are being used by juvenile salmon [1] and, in 2009, herring spawned along the shoreline of Habitat Island. Other marine life comprising the False Creek ecosystem have also benefited. Shorebirds, seabirds and waterfowl are foraging within the SEFC shoreline environment. Raptors have roosted upon the snags. Seals have hauled out on the western spit of Habitat Island. 
Life of the False Creek ecosystem also includes the residents of Vancouver. The character of the design reflects the overall character of shorelines within and near urban centres that have retained natural features. The shoreline appears to retain features of False Creek that pre-date development. These features engage residents and expose them to marine life of the inlet. Seasonal pulses of activity, such as spawning by herring, foster an appreciation of the dynamic nature of coastal British Columbia. This appreciation can evolve into a sense of ownership and stewardship, and, ultimately, conservation of the ecosystem of which the residents of Vancouver are an integral component.

\section{References}

[1] Wernick, B.G., Nikl, L.H. and Adams, M.A., From brown shore to green: Redevelopment of the Southeast False Creek Lands in Vancouver, Canada. (in press) In preparation for Environmental Impact 2012.

[2] False Creek Watershed Society. False Creek's Watershed: Then \& Now. www.falsecreekwatershed.org/pdfs/falsecreek_swatershedfinal.pdf

[3] Society for Ecological Restoration. The SER International Primer on Ecological Restoration. International Science \& Policy Working Group. www.ser.org and Tucson: Society for Ecological Restoration International, 2004.

[4] Bradshaw, A.D., Underlying principles of restoration. Canadian Journal of Fisheries and Aquatic Sciences, 53(suppl.1), pp. 3-9, 1996.

[5] Bradshaw, A.D., Introduction and Philosophy (Chapter 1). Handbook of Ecological Restoration. Volume 1: Principles of Restoration, eds. M.R. Perrow and A.J. Davy, Cambridge University Press: Cambridge, UK, pp. 39, 2002.

[6] Fowler, H.W. and Fowler, F.G. (eds). The Oxford English Dictionary. $6^{\text {th }}$ Edition, Oxford University Press: Oxford, UK, 1971. Cited in Bradshaw (1996 and 2002).

[7] Grabowski, J.H., Randal Hughes, A., and Kimbro, D.L., Habitat complexity influences cascading effects of multiple predators. Ecology, 89, pp. 34133422, 2008.

[8] Hovel, K.A., and Fonseca, M.S., Influence of seagrass landscape structure on the juvenile blue crab habitat-survival function. Marine Ecology Progress Series, 300, pp. 179-191, 2005.

[9] Ricketts, E.F., Calvin, J., Hedgpeth, J.W. and Phillips, D.W., Between Pacific Tides, Sanford University Press: Stanford, CA, USA, 1985.

[10] Williams, G.D., and Thom, R.M., Marine and Estuarine Shoreline Modification Issues. White Paper. Washington Department of Fish and Wildlife; Washington Department of Ecology; and, Washington Department of Transportion. Seattle, WA, USA, 2001. 